\title{
A new Culicoides (Diptera: Ceratopogonidae) of the Reticulatus species group from Brazilian Amazon Region
}

\author{
Maria Luiza Felippe-Bauer ${ }^{1 /}$, Camila Pinto Damasceno ${ }^{1,2}$, \\ Rosimeire Lopes da Trindade ${ }^{3}$, Victor Py-Daniel ${ }^{2}$ \\ 'Laboratório de Diptera, Instituto Oswaldo Cruz-Fiocruz, Av. Brasil 4365, 21040-900 Rio de Janeiro, RJ, Brasil
${ }^{2}$ Laboratório de Etnoepidemiologia, Instituto Nacional de Pesquisas da Amazônia, Manaus, AM, Brasil
${ }^{3}$ Coordenação de Zoologia, Entomologia, Museu Paraense Emílio Goeldi, Belém, PA, Brasil
}

A new species of the Culicoides reticulatus species group, Culicoides kuripako Felippe-Bauer, is described and illustrated based on females and male specimens from the states of Amazonas and Pará, Brazil. The new species is compared with its similar sympatric congener, Culicoides paucienfuscatus Barbosa.

Key words: Amazonas - Brazil - Culicoides kuripako sp. nov. - neotropical bloodsucking midges - Pará

During entomological surveys in the state of Amazonas (AM) and Pará (PA), Brazil, collected specimens of Culicoides included an undescribed species very similar to a congener that belongs to the reticulatus species group, Culicoides paucienfuscatus Barbosa. C. paucienfuscatus is a neotropical widespread species which occurs between Costa Rica through Central and South America to Peru, including Trinidad, Venezuela, Bolivia and Amazon Region of Brazil (AM and PA) (Borkent \& Spinelli 2007). The purpose of this paper is to describe a new species based on female and male specimens captured while biting humans and with CDC light trap and to supply taxonomic characters for separation of these two similar sympatric species.

\section{MATERIALS AND METHODS}

The specimens are slide-mounted in phenol-balsam in the manner described by Wirth and Marston (1968). The new species is deposited in National Institute of Amazonian Research/Laboratory of Ethnoecology and Ethnoepidemiology (Invertebrates Collection) (INPA/LETEP), Emílio Goeldi Museum (Invertebrates Collection) (MPEG) and Oswaldo Cruz Institute (Ceratopogonidae Collection) (CCeIOC), Brazil. Diagnostic characters were illustrated using a camera lucida. Microphotographies of the wings were taken with a Nikon Eclipse E-800. The general terminology used is that employed for Culicoides by Spinelli et al. (2005). Terms for wing veins follow the system of the Manual of Nearctic Diptera (McAlpine et al. 1981), with modifications proposed by Szadziewski (1996). The measurements of the spermathecae are in micrometers and those of the wings are in millimeters. Meristic information is given as range, following by the mean and number of specimens examined.

Financial support: CAPES (CPD), FAPEAM (0348), FINEP (0852), CNPq + Corresponding author: mlfbauer@ioc.fiocruz.br

Received 8 April 2010

Accepted 10 June 2010

\section{RESULTS}

Culicoides kuripako Felippe-Bauer, sp. nov.

(Figs 1-11)

Diagnosis - Only species of the reticulatus species group with scutum with prominent pattern of oval yellowish patches, poststigmatic pale spot in cell $r_{3}$ inverted L-shaped, veins $\mathrm{M}_{1}, \mathrm{M}_{2}, \mathrm{CuA}_{1}$ pale, $\mathrm{CuA}_{2}$ pale with dark apex or entirely pale, male genitalia with a ventral lobe in the distal portion of the stem of the parameres.

Female - Wing length 0.89-1.05 $(0.98, \mathrm{n}=11) \mathrm{mm}$; breadth $0.43-0.48(0.46, \mathrm{n}=11) \mathrm{mm}$.

Head: brown. Eyes (Fig. 4) bare, narrowly separated by a distance of the diameter of $1 / 2$ ommatidium. Pedicel brown; flagellum (Fig. 5) pale brown; antennal ratio 1.12-1.23 (1.16, $\mathrm{n}=10)$; sensilla coeloconica on flagellomeres 1, 5-8; one or two on 1 , one on 5 , three on 6-8. Palpus (Fig. 6) brown; 3rd segment slightly swollen distally, with a moderately deep sensory pit on distal portion; palpal ratio 2.2-2.7 $(2.5, \mathrm{n}=11)$. Proboscis moderately long; $\mathrm{P} / \mathrm{H}$ ratio $0.81-0.94(0.87, \mathrm{n}=11)$; mandible with 11-13 $(\mathrm{n}=5)$ teeth.

Thorax: brown. Scutum with prominent pattern of oval yellowish patches; scutellum yellowish on sides; postscutelum brown. Legs mostly brown; femora with subapical pale bands, tibiae with subbasal pale bands; hind tibia pale apically (Fig. 9); hind tibial comb (Fig. 8) with four spines, the two nearest the spur longest, subequal. Tarsi pale, tarsomeres of hind leg darkest. Wing (Figs 1,2) with pattern as in photographs: second radial cell in dark spot; pale spot over cross vein $\mathrm{r}-\mathrm{m}$ very large, extending from vein $\mathrm{CuA}$ to costal wing margin, poststigmatic pale spot in cell $r_{3}$ inverted L-shaped, nearly isolating a small dark spot behind second radial cell; distal pale spot in cell $r_{3}$ usually broadly abutting wing margin (Fig. 1), or nearly rounded and not reaching wing margin (Fig. 2); cell $\mathrm{m}_{1}$ with two pale spots, proximal one merges into transverse pale band of wing, distal one usually large and meeting wing margin (Fig. 1) or smaller than proximal one and not meeting wing margin (Fig. 2); cell $\mathrm{m}_{2}$ with a small 
rounded pale spot behind medial fork and two distal pale spots, the proximal one connected with the first pale spot of cell $\mathrm{m}_{1}$, the distal one abutting wing margin; cell cua with a round pale spot nearly reaching wing margin; anal cell with two distal rounded pale spots; wing base with a broad pale spot extending from costal margin to anal cell; veins $\mathrm{M}_{1}, \mathrm{M}_{2}, \mathrm{CuA}_{1}$ pale; $\mathrm{CuA}_{2}$ pale with dark apex or entirely pale in some specimens; macrotrichia on distal half of wing, a few in cua and anal cell; costal ratio $0.60-0.62$ $(0.61, \mathrm{n}=11)$. Halter pale.

Abdomen: brown. Two unequal sized ovoid spermathecae (Fig. 7) with long necks (11-13 $\mu \mathrm{m})$, measuring 48 by $37 \mu \mathrm{m}$ and 40 by $32 \mu \mathrm{m}(\mathrm{n}=10)$, respectively. Long rudimentary third spermathecae $(27 \mu \mathrm{m})$, sclerotized ring present.

Male - Similar to female with usual sexual differences. Sensilla coeloconica on flagellomeres 1, 6-10. Wing length $0.87 \mathrm{~mm}$, breadth $0.35 \mathrm{~mm}$, costal ratio 0.56 , pattern as in Fig. 3. Terminalia (Fig. 10): 9th sternum with deep posteromedial excavation, ventral membrane without definite spicules on slide mounted specimen; 9th tergum tapering, with long, slender, subparallel, apicolateral processes without posteromedial notch. Gonocoxite 2.5 times longer than broad, ventral root stout with hell-like expansions, dorsal root long, slender; gonostylus tapering distally, distal portion with broad bent tip. Aedeagus (Fig. 10) with basal arch extending to $1 / 2$ of total length; basal arms moderately stout; distal portion slender and rounded, irregularly ending. Parameres (Fig. 11) separate, each with dark basal knob; stem long, slender, bent
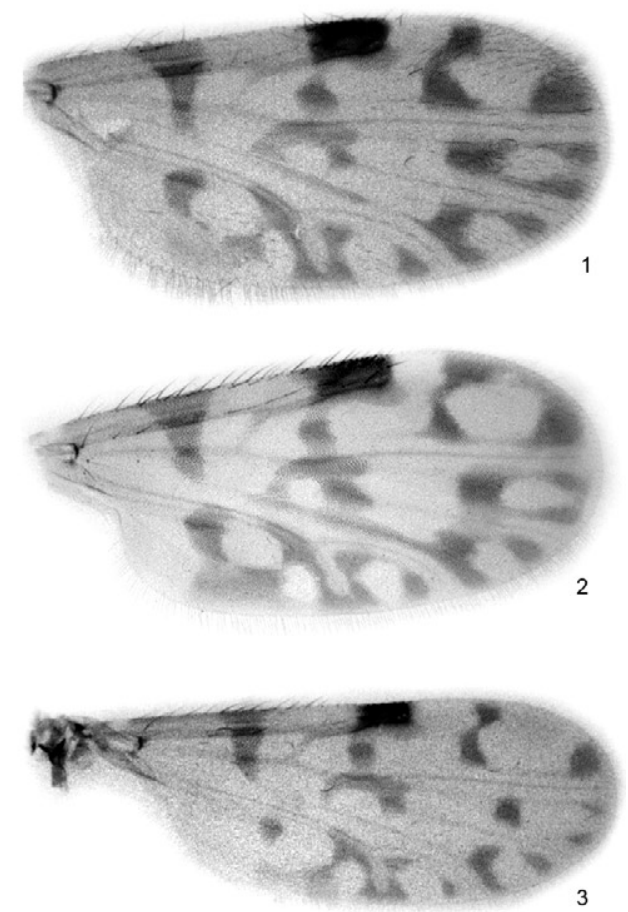

Figs 1-3: wing photograph of Culicoides kuripako Felippe-Bauer sp. nov. 1, 2: female; 3: male.

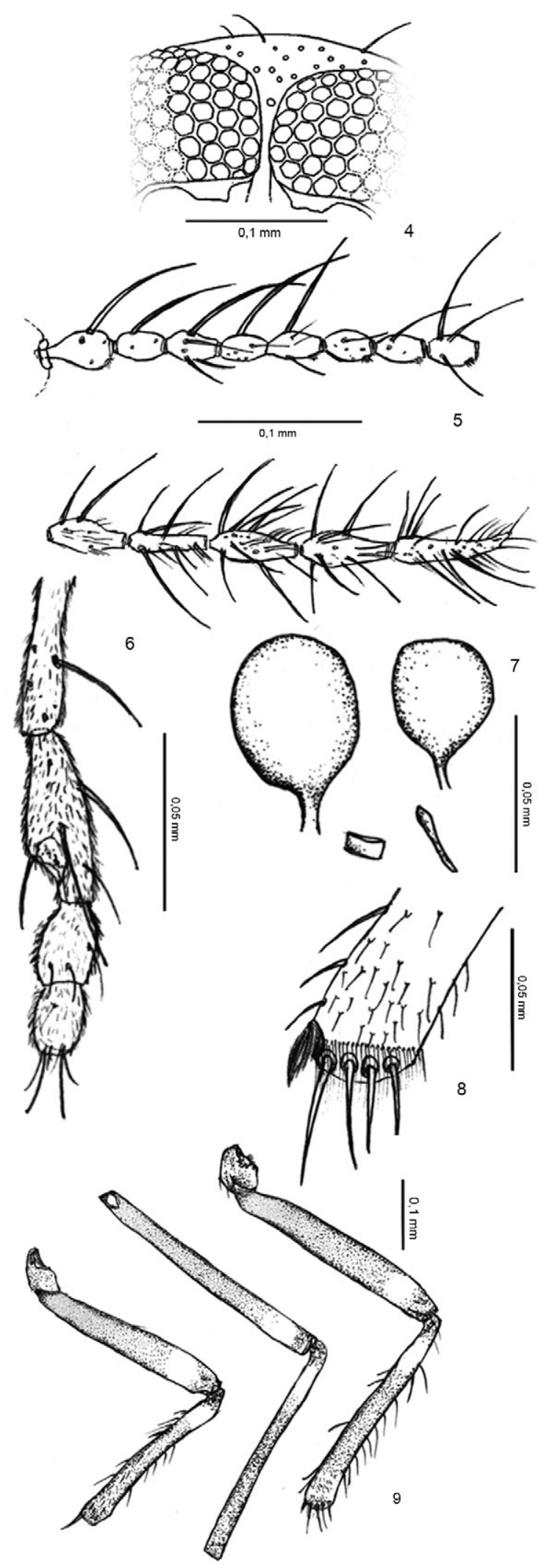

Figs 4-9: Culicoides kuripako Felippe-Bauer sp. nov., female. 4: dorsal portion of head capsule in anterior view; 5: flagellomeres 1-13; 6: palpus, lateral view; 7: spermathecae, 3rd psermatheca and sclerotized ring present; 8: hind tibial comb; 9: legs (left-right) fore, mid and hind. 


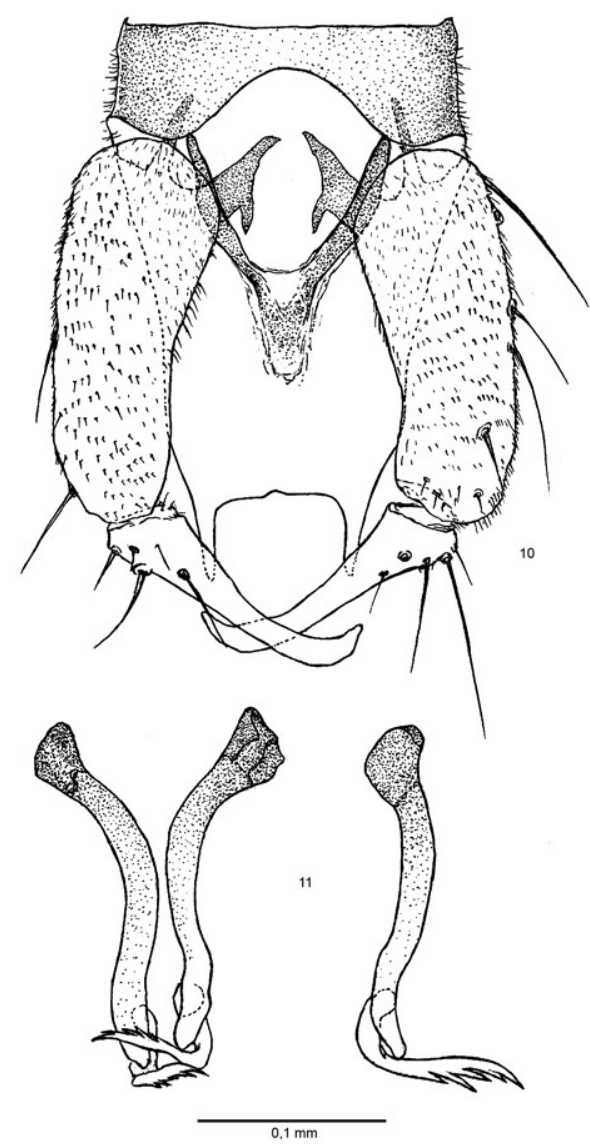

Figs 10-11: Culicoides kuripako Felippe-Bauer sp. nov., male. 10: genitalia, parameres removed; 11: parameres (the one of the right in lateral view).

near base, with subapical ventral lobe; apical portion tapered, abruptly bent, ventral and internally directed, with lateral fringe of five spicules.

Type data and depository - Holotype female, Serra das Andorinhas, São Geraldo do Araguaia, PA, 26-27.I.2006, CDC light trap, cerrado, Guimarães col. Allotype male, Morro de Santa Cruz, Içana, São Gabriel da Cachoeira $\left(01^{\circ} 04^{\prime} 21,1^{\prime}\right.$ N $67^{\circ} 35$ '52,1'”), AM, 30.XI-04.XII.2007, CDC light trap, Damasceno col. Paratypes 19 females as follows: three of the same data as holotype; 14 of the same data as holotype, except 21-22.I.2006, 24-25.I.2006, 3031.I.2006, 19-22.IV.2006, 26-27.IV.2006, 29-30-.XI.2006, 1-2.XII.2006, 4-5.XII.2006; one of the same data as allotype, except 23.II.2008, biting human, 6-6:30 am, $\left(01^{\circ} 03^{\prime} 44,5^{\prime} \mathrm{N}\right.$
67³5’36,0'W); one from Marabá, PA, 31.V.2009, CDC light trap $(3 \mathrm{~m})$. Holotype and 15 paratypes deposited in MPEG; allotype and one paratype in INPA/LETEP (\#6302, $\mathrm{m}, \mathrm{f})$; three paratypes in CCeIOC (\#461-463).

\section{Distribution - Brazil (AM, PA).}

Etymology - This species is named in honor of the Kuripako Indians, inhabitants of the type locality in the Amazon Region.

Taxonomic discussion - C. kuripako sp. nov. is a typical member of the reticulatus species group. It is very similar to C. paucienfuscatus, also known to occur in AM, especially by the wing pattern and by the meristic characters. In the key to the Amazon species of Culicoides by Wirth and Blanton (1973), C. kuripako keys out to couplet 29 and can be distinguished from C. paucienfuscatus by the vein $\mathrm{CuA}_{2}$ entirely pale or with dark apex $\left(\mathrm{CuA}_{2}\right.$ entirely in a dark spot in C. paucienfuscatus) and by the stem of the parameres with a distal ventral lobe (without ventral lobe in C. paucienfuscatus).

\section{ACKNOWLEDGEMENTS}

To Tiago do Nascimento da Silva, for the confection of the figures, to Rodrigo Mexas, for assistance in the wing photographs and plates of figures, to Eloy Castellón, for the loan of CDC light trap, to Escola Agrotécnica de São Gabriel da Cachoeira and residents, for their assistance in the capture in the state of Amazonas, and to Domingos Guimarães, for assistance in the collection in the state of Pará.

\section{REFERENCES}

Borkent A, Spinelli GR 2007. Neotropical Ceratopogonidae (Diptera: Insecta). In J Adis, JR Arias, G Rueda-Delgado, KM Wantzen, Aquatic biodiversity in Latin America (ABLA), vol. 4, Pensoft, Sofia, p. 1-198.

McAlpine JF, Peterson BV, Shewell GE, Teskey HJ, Vockeroth JR, Wood DM 1981. Manual of Nearctic Diptera, vol. 1, Monograph 27, Agriculture, Research Branch Agriculture Canada, Otawa, 674 pp.

Spinelli GR, Ronderos MM, Díaz F, Marino PI 2005. The bloodsucking biting midges of Argentina (Diptera: Ceratopogonidae). Mem Inst Oswaldo Cruz 100: 137-150.

Szadziewski R 1996. Biting midges from lower cretaceous amber of Lebanon and upper cretaceous Siberian amber of Taimyr (Diptera: Ceratopogonidae). Studia Dipterologica 3: 23-86.

Wirth WW, Blanton FS 1973. A review of the maruins or biting midges of the genus Culicoides (Diptera: Ceratopogonidae) in the Amazon Basin. Amazoniana 4: 405-470.

Wirth WW, Marston N 1968. A method for mounting small insects on microscope slides in Canada balsam. Ann Entomol Soc Am 61: 783-784. 